\title{
EFEKTIVITAS MODELPEMBELAJARAN KOOPERATIF TIPE TALKING CHIPS TERHADAP KEMAMPUAN MENULIS TEKS PROSEDUR KOMPLEKS SISWA KELAS XI SMA NEGERI 7 MEDAN TAHUN PEMBELAJARAN 2019/2020
}

\section{Oleh}

\author{
${ }^{1}$ Yandi Johannes Bosko Marbun, ${ }^{2}$ Atika Wasilah \\ Prodi Pendidikan Bahasa dan Sastra Indonesia, Univers itas Negeri Medan \\ Email: ${ }^{1}$ yandimarbun31@gmail.com, ${ }^{2}$ atika_wasilah@ yahoo.com)
}

\begin{abstract}
ABSTRAK
Penelitian ini bertujuan untuk mengetahui keefektifan model pembelajaran kooperatif tipe talking chipsterhadap kemampuan menulis teks prosedur kompleks siswa kelas XI SMA Negeri 7 Medan Tahun Pembelajaran 2019/2020.Sampel penelitian ini adalah kelas XI-IPA 1 berjumlah 34 dan kelas XI- IPA 2 yang berjumlah 34 siswa. Penelitian ini menggunakan metode eksperimen Randomized Subject, Posstest Only Control Groub Design. Instrumen yang digunakan adalah tes objektif esai.Berdasarkan pengolahan data diperoleh hasil poss-test (Kontrol) dengan rata-rata $=70$ dan standar deviasi $=7.17$. Sedangkan hasil posttest $($ Eksperimen) dengan rata-rata $=80.58$ dan standar deviasi $=7.74$. Dari uji data kelas kontroldan kelas eksperimen diketahui bahwa kedua data tersebut berdistribusi normal. Data post-test (Kontrol) diperoleh $\mathrm{L}_{\text {hitung }}<\mathrm{L}_{\text {tabel }}(0.140<0.151)$ dan data post-test (Eksperimen)diperoleh $\mathrm{L}_{\text {hitung }}<\mathrm{L}_{\text {tabel }}(0.137<0.151)$. Sedangkan dari uji homogenitas diperoleh bahwa sampel penelitian ini berasal dari kelompok yang homogen yaitu $F_{\text {hitung }}<F_{\text {tabel }}(1.07<1.80)$. Setelah uji normalitas dan homogenitas dilakukan, diperoleh $t_{o}=5.81$. Selanjutnya $t_{o}$ Dikonsultasikan dengan $\mathrm{t}$ tabel pada taraf signifikan 5\% dengan $\mathrm{df}=\mathrm{N}-1=68-1=67$ diperoleh taraf signifikan 5\%=2,00. Oleh karena $t_{o}$ Yang diperoleh lebih besar dar $t_{\text {ta bel }}$ Yaitu $5.81>2,00$, maka $H_{a}$ Diterima.Hal ini membuktikan bahwa model pembelajaran kooperatif tipe talking chips efektif digunakan terhadap kemampuan menulis teks prosedur kompleks pada siswa kelas XI SMA Negeri 7 Medan Tahun Pembelajaran 2019/2020.
\end{abstract}

Kata Kunci : Efektivitas,model Pembelajaran Talking Chips, Menulis Teks Prosedur Kompleks

\section{A. PENDAHULUAN}

Keterampilan berbahasa terdiri dari empat komponen, yaitu keterampilan menyimak, keterampilan membaca, keterampilan berbicara, dan keterampilan 
menulis.Keempat keterampilan tersebut merupakan satu kesatuan. Menulis merupakan salah satu keterampilan berbahasa yang digunakan untuk berkomunikasi secara tidak langsung, tidak secara tatap muka dengan orang la in. Menulis merupakan bagian yang tidak terpisahkan dalam proses belajar yang dialami siswa selama menuntut ilmu di sekolah.

Menulis merupakan salah satu keterampilan yang harus dikuasai oleh siswa, sebab kemampuan menulis setiap siswa tidak diperoleh secara alamiah atau diwarisi dari leluhurnya.Namun, setiap siswa perlu dilatih secara sungguh-sungguh sejak dini sebagai bekal pendidikan lanjut.Melalui kegiatan menulis kita dapat menuangkan ide, pikiran, perasaan, dan gagasan, ke dalam bentuk kata, kalimat, paragraf, maupun wacana.

Mengacu pada kurikulum 2013 , pembelajaran bahasa Indonesia menuntut akan pentingnya keterampilan menulis. Dalam kurikulum baru-baru ini, pembelajaran bahasa Indonesia banyak terfokus pada teks atau disebut sebagai pembelajaran berbasis teks. Siswa dituntut untuk memproduksi teks sesuai dengan tujuan dan fungsi sosialnya. Salah satu kompetensi yang ingin dicapai oleh pembelajaran bahasa Indonesia pada kurikulum 2013 adalah siswa mampu memproduksi teks prosedur kompleks. Dengan kompetensi dasar (4.2) "Mengembangkan teks prosedur dengan memperhatikan hasil analis is terhadap isi, struktur, dan kebahasaan”.Teks prosedur kompleks adalah jenis teks yang berisi langkah-langkah atau tahapan-tahapan yang ditempuh untuk mencapai suatu tujuan.

Untuk mengetahui permasalahan yang sebenarnya terjadi dalam imple mentasi kurikulum 2013 pada mata pelajaran bahasa Indonesia, khusus nya pada pembe lajaran teks prosedur kompleks, penulis melakukan wawancara terhadap guru bidang studi bahasa Indonesia, yaitu Khanafi Lubis, S.Pd. di SMA Negeri 7 Medan, didapatkan keterangan bahwa siswa mengalami kesulitan dalam menyusun ide/gagasan menjadi sebuah tulisan teks prosedur kompleks, karena pembelajaran yang dibawakan guru masih bers ifat ceramah atau satu arah.

Berdasarkan hal ini proses pembelajaran akan berlangsung dengan tidak efektif, dan tujuan pembelajaran akan sulit untuk dicapai. Kemudian, model 
pembe lajaran ekspositori yang digunakan ini kurang dapat menarik perhatian siswa dan kurang dapat mengembangkan potensi yang ada pada diri siswa agar secara leluasa dapat mengekspresikan pengetahuan dan perasaannya.Dengan model ini, guru hanya mentransfer ilmu kepada siswa sehingga siswa kurang mendapat kesempatan untuk mengekspresikan pengetahuan dan perasaannya. Kemudian, dengan model konvensional juga membuat siswa kurang semangat dalam melakukan proses pembelajaran, karena tidak diberi kesempatan untuk berperan aktif di dalam proses pembe lajaran. Dalam kondisi seperti ini siswa akan jadi tengge lam dalam kepasifan, tidak mampu mengutarakan ide atau gagasan yang ada didirinya. Hal ini terlihat je las disaat proses pembelajaran di waktu observasi. Siswa belum mendapatkan pembelajaran secara konkrit karena guru belum menggunakan model pembelajaran yang tepat.

Kemudian, diketahui dari hasil perolehan siswa di semester sebelumnya menunjukkan bahwa dalam pembelajaran menulis teks prosedur kompleks, masih banyak siswa yang mendapat nilai dibawah Kriteria Ketuntasan Minimal (KKM).KKM untuk menulis teks prosedur kompleks adalah 75. Diperoleh hasil bahwa 19 dari 31 siswa masih memperoleh nilai dibawah 75 sedangkan 12 siswa mendapat nilai diatas 75. Berdasarkan perolehan nilai tersebut dapat dikatakan siswa belum mampu menulis teks prosedur kompleks sesuai dengan tujuan yang telah ditetapkan di dalam kompetensi dasar.

Kemudian, berdasarkan penelitian mengenai teks prosedur kompleks oleh Azura tahun 2007, bahwa kompetensi menulis teks prosedur kompleks siswa kelas VII SMP N 2 Percut Sei Tuan masih tergolong kurang karena rata-rata nilai siswa masih di bawah KKM. Kesimpulan penelitiannya yaitu, kemampuan menulis teks prosedur siswa kelas VII SMP Negeri 2 Percut Sei Tuan tahun pembelajaran 2017/2018 berada pada kategori kurang dengan rata-rata 69. Terdapat 6 siswa yang memperoleh skor rentang dan berada di kategori sangat baik, terdapat 6 siswa yang memperoleh skor rentang dan berada dikategori baik, terdapat 15 siswa yang memperoleh skor rentang dan berada di kategori cukup, terdapat 1 siswa 8 . 
Berdasarkan hal tersebut beliau mengatakan siswa kurang berminat dalam pembe lajaran teks prosedur kompleks.

Bertolak dari fenomena di atas, dapat dilihat dari kurang tepatnya model yang digunakan guru, sehingga menyebabkan siswa menjadi pasif atau tidak antusias dalam memberikan ide dan gagasannya, maka diperlukan upaya yang dapat dilakukan untuk memperbaiki kemampuan siswa dalam menulis teks prosedur kompleks serta meningkatkan antusias siswa supaya lebih aktif dalam belajar, yaitu dengan menggunakan Model Kooperatif tipe Talking Chips.

Dengan menggunakan model ini di yakini, siswa akan dapat meningkatkan kemampuan siswa dalam menulis teks prosedur kompleks yang cenderung rendah, dan meningkatkan keaktifan dan keantusiasan siswa dalam proses pembelajaran karena dalam model ini menggunakan chips atau dapat dikatakan tiket siswa dalam berbicara untuk memberikan ide dan gagasannya. Semua siswa juga dipastikan atau wajib menggunakan chips yang dimiliki. Dengan demikian, siswa akan dapat menggungkapkan ide atau gagasannya di depan umum dan tidak pas if lagi. Se lain itu, siswa juga dapat lebih bertanggung jawab terhadap chips, yaitu bertanggung jawab untuk menggunakan chipsdalam pembelajaran.Dalam hal ini chips yang digunakan yakni benda-benda kecil seperti kancing, kacang merah, biji kenari, pulpen, potongan sedotan, atau benda kecil lainnya.

Berdasarkan hasil penelitian terdahulu oleh Utami yang berjudul "Model Pembelajaran Kooperatif Kancing Gemerincing untuk Meningkatkan Pemahaman pada Materi Lingkaran" menunjukkan bahwa aktivitas pembelajaran siswa melalui pembelajaran matematika dengan model pembelajaran kooperatif tipe talking chips khususnya pada materi lingkaran mengalami peningkatan. Serta hasil belajar siswa melalui pembelajaran model pembelajaran kooperatif ini pada materi lingkaran menga lami peningkatan yaitu dari siklus I diperoleh rata-rata 80,2 dan meningkat menjadi 82,9 pada siklus II. Kemudian penelitian Widyarty yang berjudul "Pengaruh Model Pembelajaran Kooperatif Tipe Kancing Gemerincing Terhadap Hasil dan Minat Belajar Matematika Siswa Kelas VII SMP Dwi Sejahtera Pekanbaru menunjukkan bahwa mean hasil belajar siswa kelas yang menggunakan model 
pembe lajaran kooperatif tipe talking chips $(81,133)$ lebih tinggi dari pada mean hasil kelas konvensional $(72,4)$. Mean minat kelas yang menggunakan model pembelajaran kooperatif tipe talking chips $(90,433)$ lebih tinggi dari pada mean minat kelas konvensional $(79,133)$. Berarti hasil dan minat belajar matematika siswa yang menggunakan model pembelajaran kooperatif tipe talking chips lebih baik dari pada minat siswa yang menggunakan pembelajaran konvensional.

Berdasarkan latar belakang di atas maka peneliti tertarik untuk mengadakan penelitian untuk mengetahui Efektivitas Model Pembelajaran Kooperatif Tipe Talking Chips Terhadap Kemampuan Menulis Teks Prosedur Kompleks Siswa Kelas XI SMA Negeri 7 Medan Tahun Pembelajaran 2019/2020.

\section{B. KAJIAN TEORI}

Model Kooperatif tipe Talking Chips sering disebut model pembelajaran Kancing Gemerincing. Kegiatan model ini, masing-masing anggota kelompok mendapat kesempatan untuk memberikan kontribusi mereka dan mendengarkan pandangan dan pemikiran orang lain. Dengan proses pembelajaran seperti ini siswa akan merasa tertarik untuk belajar, karena diberikan kebebasan dalam mengungkapkan ekspresi dan pengetahuannya.

Keunggulan model ini untuk mengatasi hambatan pemerataan kesempatan yang sering mewarnai kerja kelompok.Karena dalam kerja kelompok sering ada anggota yang terlalu dominan bicara, sementara anggota lain pasif. Artinya pemerataan tanggung jawab dalam kelompok tidak tercapai, karena anggota yang pasif akan terlalu menggantungkan diri pada rekannya yang dominan (Lie, 2008: 54).Semua siswa yang ada di kelas dapat menyampaikan idenya dalam menulis teks prosedur yang sesuai dengan KD yang terdapat di da lam kurikulum.

Teks prosedur kompleks adalah teks yang berisi tentang menunjukkan dan menggambarkan proses dalam membuat, mengoperasikan atau mengoperasikan sesuatu. Ciri-ciri dari teks prosedur kompleks adalah berisikan langkah-langkah, disusun secara informatif, dijelaskan secara mendetail, bersifat objektif, langkah 
berkelanjutan dengan penjelasan, menggunakan syarat/pilihan, bersifat universal, bersifat aktual dan akurat, dan bersifat logis.

\section{METODE PENELITIAN}

Penelitian ini menggunakan metode eksperimen dengan model Two-group test only design, Merupakan eksperimen yang dilaksanakan pada dua kelompok yaitu kelompok kontrol dan kelompok eksperimen. "Metode eksperimen adalah metode yang digunakan dengan mengadakan manipulasi terhadap objek penelitian serta adanya kontrol'(M.Nazir, 2003:63). Jadi, adapun metode yang digunakan dalam penelitian ini adalah metode eksperimen dengan maksud untuk melihat akibat dari suatu perlakuan terhadap kemampuan menulis teks prosedur kompleks siswa dengan menggunakan Model Pembelajaran Kooperatif Tipe Talking Chips .

\section{HASIL DAN PEMBAHASAN PENELITIAN}

Perolehan data kemampuan menulis teks prosedur kompleks dengan menggunakan modelekspositori dapat dideskripsikan sebagai berikut :

Tabel 1

Identifikasi Kecenderungan Hasil Tes Kelas Kontrol

\begin{tabular}{c|c|c|c}
\hline INTERVAL & F. ABSOLUTE & F. RELATIVE & KATEGORI \\
\hline $85-100$ & \multicolumn{3}{c}{ Sangat baik } \\
$70-84$ & 6 & $17,7 \%$ & Baik \\
$55-69$ & 15 & $44,1 \%$ & Cukup baik \\
$40-54$ & 13 & $38,2 \%$ & Kurang baik \\
$0-39$ & & & Sangat Kurang \\
\hline Jumlah & 34 & $100 \%$ & \\
\hline
\end{tabular}

Berdasarkan tabel di atas dapat diketahui bahwa pembelajaran menulis teks prosedur kompleks menggunakan model ekspositori yang berjumlah 34 sampel terbagi atas kategori baik sekali tidak ada atau 0\%, kategori baik sebanyak 6 siswa 
atau $17.7 \%$, kategori cukup sebanyak 15 siswa atau 44.1\%, kategori kurang sebanyak 13 siswa atau $38.2 \%$, dan kategori sangat kurang tidak ada atau $0 \%$.

Perolehan data kemampuan menulis teks prosedur kompleks dengan menggunakan model pe mbelajaran kooperatif tipe talking chips dapat dideskripsikan sebagai berikut :

Tabel 2

Identifikasi Kecenderungan Hasil Tes Kelas Eksperimen

\begin{tabular}{c|c|c|c}
\hline INTERVAL & F. ABSOLUTE & F. RELATIVE & KATEGORI \\
\hline $85-100$ & 5 & $14,7 \%$ & Sangat baik \\
$70-84$ & 19 & $55,9 \%$ & Baik \\
$55-69$ & 8 & $23,5 \%$ & Cukup baik \\
$40-54$ & 2 & $5,9 \%$ & Kurang baik \\
$0-39$ & & & Sangat Kurang \\
\hline Jumlah & 34 & $100 \%$ & \\
\hline
\end{tabular}

Berdasarkan tabel di atas dapat diketahui bahwa pembelajaran menulis teks prosedur kompleks menggunakan model kooperatif tipe talking chips dengan jumlah 34 sampel terbagi atas kategori baik sekali 5 siswa atau $14.7 \%$, kategori baik sebanyak 19 siswa atau 55.9\%, kategori cukup 8 siswa atau 23.5\%, kategori kurang sebanyak 2 atau 5.9\%, dan kategori sangat kurang tidak ada atau 0\%.

Setelah dilakukan penelitian pada kelas kontrol dengan sampel $34 \mathrm{siswa}$ dan kelas eksperimen 34 siswa maka, didapat model pembelajaran kooperaif tipe talking chips lebih efektif dibandingkan dengan model pembelajaran ekspositori terhadap kemampuan menulis teks prosedur kompleks siswa kelas IX SMA Negeri 7 Medan. Dengan rata-rata pada kelas kontrol sebesar 70 dan rata-rata kelas eksperimen sebesar 80,58dengan selisih nilai 10,58. Dinilai dari aspek penilaian isi, struktur, dan kebahasaan.Berdasarkan kategori penilaian menurut Sudijono (2007:43) nilai 80,58 tergolong kedalam kategori baik. Sedangkan di sekolah KKM yang ditetapkan itu 
yakni 75. Maka, pembelajaran dengan menggunakan model kooperatif tipe talking chipsdapat digunakan dalam pembe lajaran teks prosedur kompleks.

Hal ini membuktikan bahwa model pembelajaran kooperatif tipe talking chips lebih efektif dibandingkan dengan model pembelajaran ekspositori dalam menulis teks prosedur kompleks oleh siswa kelas XI SMA Negeri 7 Medan Tahun Pembelajaran 2019/2020.

Pada penelitian ini di kelas kontrol memiliki kesimpulan bahwa masih banyak siswa yang belum tuntas sesuai dengan KKM yang telah ditetapkan sebesar 75 pada materi penulisan teks prosedur kompleks.Hasil tes kelas kontrol dengan menggunakan model pembelajaran ekspositori hanya 13 siswa yang mencapai KKM. Sedangkan pada kelas eksperimen dengan menggunakan model pembelajaran kooperatif tipe talking chips terdapat 29 siswa yang mencapai nilai di atas KKM. Sejalan dengan pendapat Wahyudi Utomo (2007:49), yang menyatakan model pembelajaran talking chips merupakan salah satu model pembelajaran yang bersifat koorperatif, yang membuat siswa belajar secara berkelompok dan saling membantu satu sama lain. Sehingga dengan model pembelajaran seperti ini akan sangat membantu siswa yang kurang paham. Sehingga menghasilkan hasil belajar yang baik sesuai dengan tujuan pembe lajaran yang telah ditetapkan diawal.

Model pembe la jaran ekspositori berada di kategori cukup karena dalam proses pembe lajaran hanya berfokus pada guru. Siswa hanya dapat menerima informasi dari guru secara satu arah atau siswa tidak dikonstruksikan untuk saling bertukar pendapat satu dengan siswa yang lainnya sehingga kurang dalam mengembangkan kemampuan kognitif dan sosial antar siswa dan guru. Siswa merasa kurang termotivasi karena proses pembelajaran yang jenuh dan tidak menarik. Proses pembelajaran seperti ini dapat memberi dampak yang kurang baik terhadap pemahaman siswa tentang materi pembelajaran.

Model kooperatif tipe talking chips ini lebih baik dari model pembelajaran ekspositori karena model kooperatif tipe talking chpis difokuskan pada komunikasi antar siswa dengan siswa lain secara berkelompok, dan guru sehingga siswa dapat lebih aktif dalam proses pembelajaran, kemudian membuat siswa lebih kritis dalam 
berpikir dan memberikan gagasannya serta membuat siswa dapat bersikap tegas. Proses pembelajaran dapat berlangsung lebih me narik dengan suasana kompetitif. Hal tersebut memiliki dampak yang bagus dalam proses pembelajaran sehingga membuat pemahaman siswa bertambah.

\section{E. KESIMPULAN}

Berdasarkan hasil penelitian dan pembahasan tentang kemampuan menulis teks prosedur kompleks siswa kelas XI SMA Negeri 7 Medan tahun pembelajaran 2019/2020, maka dapat disimpulkan beberapa hal di bawah ini. Kemampuan menulis teks prosedur kompleks siswa kelas XI SMA Negeri 7 Medan tahun pembelajaran 2019/2020 dengan model pembelajaran ekspositori nilai rata-rata 70. sedangkan dengan menggunakan model pe mbelajaran kooperatif tipe talkingchips nilai rata-rata 80.58. maka dapat disimpulkan bahwa model pembelajaran kooperatif tipe talkingchips lebih efektif digunakan daripada model pembelajaran ekspositori terhadap kemampuan menulis teks prosedur kompleks siswa ke las XI SMA Negeri 7 Medan tahun pembelajaran 2019/2020.

\section{F. SARAN}

Berdasarkan kesimpulan di atas, maka sebagai tindak lanjut penelitian ini dikemukakan saran-saran sebagai berikut. (1) Berdasarkan hasil penelitian, model pembe lajaran kooperatif tipe talkingchips efektif terhadap kemampuan siswa menulis teks prosedur kompleks. Oleh Karena itu, model ini dapat dijadikan sebagai salah satu alternatif pembelajaran dalam proses belajar mengajar di kelas. (2) Penerapan model pembelajaran kooperatif tipe talkingchips di dalam proses pembelajaran, diperlukan pemahaman guru yang lebih baik lagi, baik dari segi persiapan, alokasi waktu, pelaksanaan hingga evaluasi agar harapan untuk meningkatkan kemampuan siswa dalam menulis teks prosedur kompleks tercapai. (3) Bagi peneliti, selanjutnya disarankan agar tetap memperhatikan perkembangan model pembelajaran yang efektif, inovatif dan menarik sehingga dapat lebih meningkatkan kemampuan siswa dalam menulis teks prosedur kompleks. 


\section{DAFTAR PUSTAKA}

Azura.2017. Kemampuan Menulis Teks Prosedur Siswa Kelas VII SMP Negeri 2 Percut Sei Tuan Tahun Pembelajaran 2017/2018. Jurnal Unimed.

Lie. 2008. Cooperative Learning Mempraktikan Cooperative Learning diRuangruang Kelas. Jakarta: Grasindo

Nazir, Moh. 2013. Metode penelitian.Bogor :Ghalia Indonesia

Rini, Utami. (2015). Model Pembelajaran Kooperatif Kancing Gemerincing untuk Meningkatkan Pemahaman Siswa Pada Materi Lingkaran. Pekalongan.Universitas Pekaongan.

Sudijono,Anas.2007. Pengantar Statisik Pendidikan. Jakarta:Raya Graf indo Prasada 